Mateja Jerman

Slavka Kavčič ${ }^{* *}$

Bogdan Kavčič**
UDK 347.77:334.724>:658.511:657.375>

(497.5:497.4:437.1:430:73)"2004/2008"

Original scientific paper

Izvorni znanstveni rad

\title{
THE SIGNIFICANCE OF INTANGIBLES: A COMPARATIVE ANALYSIS BETWEEN CROATIA, SLOVENIA, CZECH REPUBLIC, GERMANY AND THE USA
}

\begin{abstract}
According to the growing importance of intangible assets, the research aims to investigate the significance of intangibles for Croatian, Slovenian, Czech, German and US publicly traded companies. The analysis is focused on intangibles that meet the criteria for the recognition in financial accounts. The results of the analysis prove that in the period 2004-2008 intangibles constitute an important asset for traditional market economies, which does not result for post-transition and transition economies, despite the fact that many analyses underline their growing significance in today's business environment. Independent t-test was used to test a difference between selected companies. A future research approach should analyze the proportion of intangibles that do not meet the criteria for their recognition and found out if transition economies actually possess a significantly lower proportion of intangibles. ${ }^{\dagger}$
\end{abstract}

JEL: $M 41, M 48$

Key words: intangible assets, goodwill, comparative analysis, financial reporting

\section{INTRODUCTION}

In today's knowledge economy the rising importance of intangible assets has driven its attention (Hussi and Ahonen, 2002, Gerpott, Thomas and Hoffmann, 2008). Furthermore case studies and analysis have provided evidence that intangible assets are the fundamental source of competitive advantages for firms in most industries (García-Ayuso, 2003). The characteristics of the economy changed from the industrial one to today's more service and information oriented. The traditional financial accounts changed over the last decades (Brännström and Giuliani, 2009). According to Edvinsson (2000) the future value creation is in the shaping of intangibles. Accounting changes in recent years have increasingly recognized the importance of intangibles, such as intellectual capital and goodwill (Dunse, Hutchinson and Goodacre, 2004).

In accordance with an increasing number of mergers and acquisitions (Mergerstat, 2009), the importance of goodwill as an intangible assets became apparent. Acquisitions reveal the hidden value of intangible assets (Boekenstein, 2009), that previous did not meet the criterion for their recognition. The results of Boekenstein's study (carried out for pharmaceutical sector) reveled that in mergers and acquisitions the total value of the acquired company increases approximately six times. Knowledge-related assets including goodwill are primarily responsible for this increase. A similar study was performed also by Busacca and Maccarone

\footnotetext{
* University of Primorska, Faculty of Management Koper, Slovenia. Cankarjeva 5, 6000 Koper, e-mail: mateja.jerman@fm-kp.si.

** University of Ljubljana, Faculty of Economics, Slovenia. Kardeljeva pl. 17, 1000 Ljubljana, e-mail: slavka.kavcic@ef.uni-lj.si.

*** Faculty of Commercial and Business Sciences, Slovenia. Lava 7, 3000 Celje, e-mail: bogdan.kavcic@telemach.net.

$\dagger$ Paper received 1 November 2009.
} 
(2007) who found out, that the most important sources of value for the telecommunications industry are represented by intangibles.

According to the rising phenomenon of intangibles the analysis aims to analyze the significance of identifiable intangible assets for Croatian publicly traded companies, taking part of Croatian stock exchange index CROBEX. Croatian companies are subject of comparison with Slovene, Czech, German and American publicly traded companies. American companies were selected as they represent the most developed traditional market economy. On the other hand Germany is a representative European traditional market economy. Croatia, as a transition economy is additionally compared with post-transition economies, which are in our case Slovenia and Czech Republic (for characteristics see Dolenc, 2009 and Stubelj, 2009). According to the growing importance of goodwill (related to the fact that many intangibles still do not meet the criteria for their recognition) the paper additionally analysis its importance in the structure of intangible assets.

The research carried out by Lahovnik (Lahovnik, 2000) provided evidence that in 39, $5 \%$ of Slovene acquisitions the acquirer paid for the acquiree at least $50 \%$ less than its book value (recognition of negative goodwill). In the case of Polish companies even Schroeder (2007) found out that the recognition of negative goodwill was very frequent. The results imply evidence that in the period of transition companies do not posses intangible assets which are not recognized in the balance sheet as the acquirers were not willing to pay for companies more than their book value. Consequently in the period of transition instead of goodwill, the acquirer often recognizes negative goodwill, which is not a typical phenomenon for traditional market economies. According to stated characteristics of the transition, an obvious hypothesis for post-transition and transition economies would be the following:

$H_{1}=$ The significance of intangibles is less important for post-transition and transition economies in comparison with traditional market economies,

$\mathrm{H}_{2}=$ The share of goodwill for post-transition and transition economies is insignificant in comparison with traditional market economies,

The paper is structured as follows. After the introduction, the accounting for intangibles background is presented. In the third part the data collection and research methodology are explained. The results of the analysis and discussion are presented in the fourth part. The fifth part draws the conclusion.

\section{ACCOUNTING FOR INTANGIBLES}

In the current literature we can found an abundance of definitions as to what intangible assets are, but there still no general accepted definition that could be adopted internationally (Kristandl and Bontis, 2007). IFRS define intangible assets as identifiable non-monetary assets without physical substance (IAS 38.8), while Lev and Daum (2004) define intangibles as capabilities and "potential" for future growth and income. According with the International accounting standards (IAS 38.9) entities most often recognize intangible resources as scientific or technical knowledge, design and implementation of new processes or systems, licences, intellectual property, market knowledge and trademarks (including brand names and publishing titles).

After the initial recognition, intangibles have to be arranged in groups with definite and indefinite useful lives. Assets with indefinite useful lives are subject of annual impairment, while those that do have a definite useful live are still subject of amortization. For the measurement after its initial recognition a company shall choose either a cost or the revaluation model. In accordance with the cost model an intangible asset is measured at its cost less any accumulated amortization and any accumulated impairment loss, while 
revaluation model requires that it has to be carried at the revaluated amount less any accumulated amortization and impairment losses.

The most controversial topic concerning intangibles is undoubtedly the recognition of goodwill. Goodwill represents the residual between the purchase price of an entity and its fair value of net assets. In accounting terms it can be recognized in financial accounts just in cases of mergers and acquisitions. There is no internationally accepted definition, nor a widely accepted accounting approach for its measurement. The majority of definitions state that goodwill is a claim for future benefits (Seetharaman, Balachandran and Saravanan, 2004), but there is no clear definition of what the elements of goodwill are (as it captures a wide range of intangibles that do not meet the recognition criteria). According to the standard for business combinations from 2004, goodwill acquired in a business combination was initially measured at its cost, which exceeded the acquirer's interest in net fair value of the identifiable assets, liabilities and contingent liabilities.

Many changes in the field of accounting for goodwill demonstrate that there is no evidence about its useful life, whether it has to be tested for impairment or amortized and even if it has to be recognized as an asset or not. Goodwill can be recognized only if it is acquired in a business combination. Internally generated goodwill can not be recognized as an asset because it is not an identifiable resource controlled by the entity that can be measured reliable (IAS 38.49). According to the current accounting approach, companies that prefer organic growth can not recognize internally generated goodwill which consequently leads to noncomparable financial accounts (Seetharaman et al., 2004).

Despite many efforts of standard preparers to provide an adequate accounting approach to account for intangibles, traditional accounts still face many problems concerning their initial recognition and subsequent measurement.

\section{III.DATA COLLECTION AND RESEARCH METHODOLOGY}

For the purposes of the analysis the sample of Croatian, Slovenian, Czech, German and US publicly traded companies was selected. The sample includes Croatian companies that were included in Croatian stock exchange index CROBEX (24 companies). Croatian companies were subject of comparison with Slovene companies, included in Slovenian stock exchange index SBI 20 (15 companies), Czech companies included in the stock index PXGLOB (25 companies), German companies included in German stock exchange index DAX (30 companies) and US publicly traded companies included in American index Dow Jones (30 companies). The data were selected for companies that were included in stated indexes on the day of $28^{\text {th }}$ October 2008.

This sample of companies was selected because of their data availability, as they provide a greater extent of disclosures in comparison with smaller companies. The selected European companies prepare their annual accounts in accordance with IFRS which require a certain extent of disclosures that are not so comprehensive for smaller companies. The research was limited to the sample of publicly quoted companies as they use the IFRS which ensure international comparability of selected European accounts. The collected data were selected on the basis of publicly available consolidated annual accounts and notes to consolidated annual accounts for the period 2004-2008. The study is focused on intangibles that meet the criterion for their recognition in financial accounts; non-identifiable intangibles (often categorized as intellectual capital), which do not meet the criterion for the recognition, are not subject of this analysis.

The means of intangible's shares, goodwill's shares and shares of goodwill in the structure of intangibles were calculated as an arithmetic mean. 
For the hypothesis testing, the independent t-test was carried out. Independent t-test was used to test a difference between two independent groups on the means of a continuous variable. T-test was used to test the differences between groups of companies that are part of selected indexes. For the purposes of testing the differences between groups of selected companies on the means of intangible's and goodwill's shares, the null and alternative hypotheses were formed:

$H_{0}=$ The means of the two groups are not significantly different and

$H_{1}=$ The means of the two groups are significantly different.

\section{IV.RESULTS AND DISCUSSION}

The results of the analysis prove that there is a significant difference $($ sig. $<0,05)$ in the share of intangibles between Croatian, German and American selected companies (the detailed results of the t-test are presented in table 3 ). The results of the t-test demonstrate that we can not prove a statistical difference between Croatian, Slovenian and Czech companies (sig. > 0,05). Differences also do not result between American and German companies. The difference between selected companies implies the fact that post-transition and transition economies operate with a significantly lower share of intangibles in comparison with traditional market economies. The only exception was present in the year 2005 for the sample of Czech companies, when the difference between Czech and German companies was not significant. The significance of intangibles in the entire structure of assets for selected companies is presented in the figure 1.

\section{Figure 1.}

The share of intangible assets in total assets for the period 2004-2008

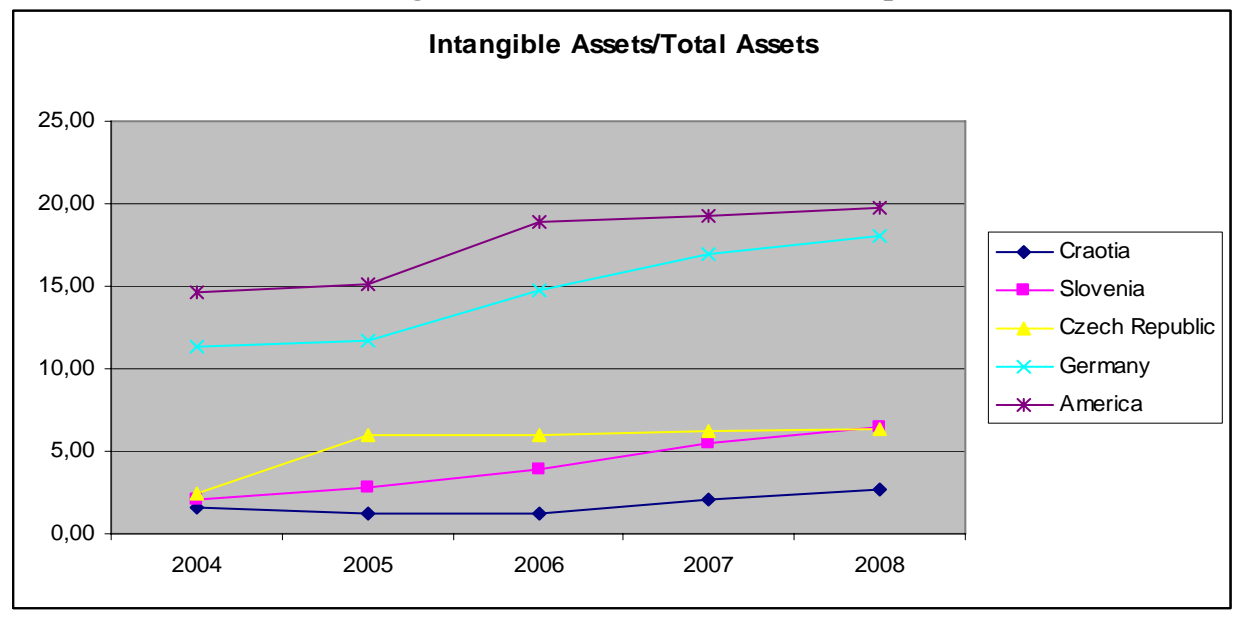

On the basis of data provided in table 1, a rising importance of intangible assets can be ascertained. A continuous growth of intangibles was presented in Slovene, German and American companies, meanwhile in Croatian (2005) and Czech (2006) companies a smaller decrease was notable. 
Table 1.

The share of intangibles for selected companies in the period 2004-2008

\begin{tabular}{|l|l|l|l|l|l|}
\hline Year & Croatia & Slovenia & Czech Republic & Germany & America \\
\hline 2004 & 1,59 & 2,11 & 2,44 & 11,33 & 14,63 \\
\hline 2005 & 1,27 & 2,79 & 6,01 & 11,66 & 15,12 \\
\hline 2006 & 1,28 & 3,96 & 5,96 & 14,72 & 18,96 \\
\hline 2007 & 2,04 & 5,55 & 6,19 & 16,91 & 19,21 \\
\hline 2008 & 2,63 & 6,50 & 6,40 & 18,10 & 19,80 \\
\hline Mean & 1,76 & 4,18 & 5,40 & 14,55 & 17,55 \\
\hline
\end{tabular}

The analysis proves that intangible assets are becoming more and more important for today's business environment, but there is still a significant difference between different types of economies. The most important significance of intangibles is present in German and American selected companies, where their share in 2008 achieved nearly one fifth of the total assets.

According to the fact that numerous researches draw attention to goodwill as a more and more important intangible asset, the research moreover investigates the importance of goodwill for selected companies. Similar to previous results, an increasing share of goodwill is evident (figure 2), but differences between economies, although some unexpected results ascertained, still can be found. Significant differences can be found for Croatia and Slovenia in comparison with Germany and America. However there are no statistical significant differences between Czech and German companies in the period 2005-2008. The comparison between Czech Republic and America revels that the differences are not ascertained only in the year 2005. The results show that in the case of goodwill Czech companies do not differ in comparison with German one. The results might be the consequence of a convergence process. Future research could provide evidence of a convergence process between market, post-transition and transition economies.

However there are still no significant differences between German and American companies, the same as between Croatian, Slovenian and Czech companies. The detailed results are presented in the table 3 .

Figure 2.

The share of goodwill in total assets for the period 2004-2008

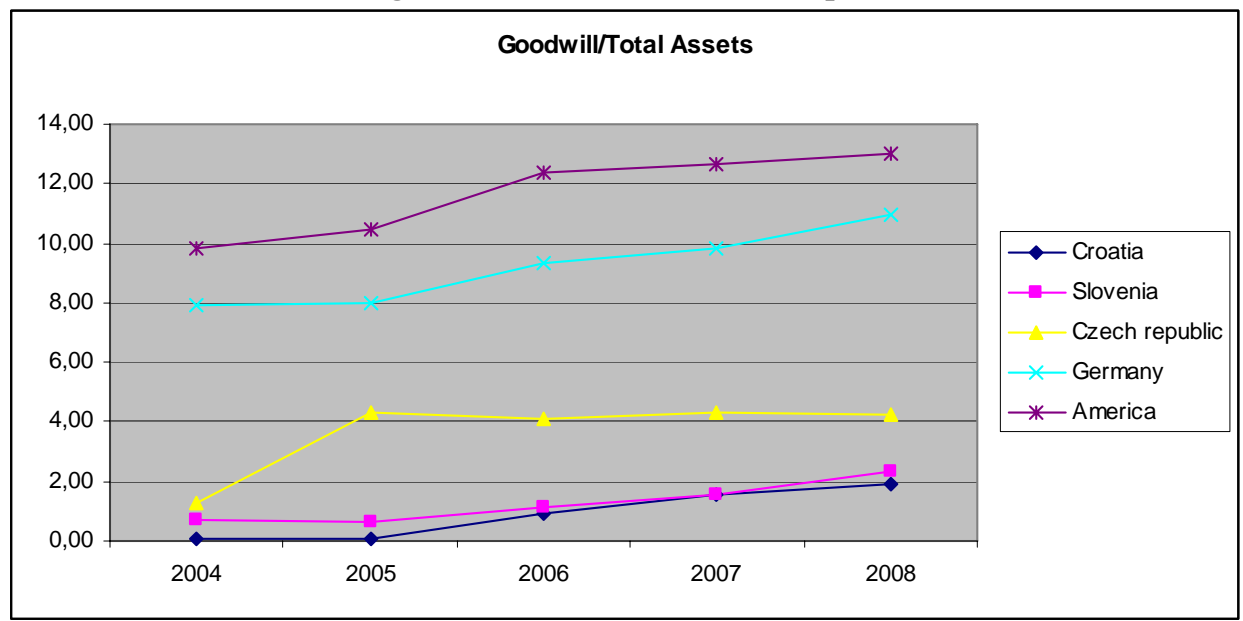


The results visible demonstrate that goodwill does not represent an important intangible asset for Croatian companies. A similar situation is present in Slovenia, while German and American companies posses a significantly higher share of goodwill (table 2). Czech companies posses a superior share of goodwill in comparison with Croatian and Slovene companies, but there is no significant difference between them.

Table 2.

The share of goodwill for selected companies in the period 2004-2008

\begin{tabular}{|l|l|l|l|l|l|}
\hline Year & Croatia & Slovenia & Czech Republic & Germany & America \\
\hline 2004 & 0,10 & 0,67 & 1,28 & 7,95 & 9,80 \\
\hline 2005 & 0,10 & 0,61 & 4,33 & 8,02 & 10,47 \\
\hline 2006 & 0,91 & 1,10 & 4,12 & 9,36 & 12,35 \\
\hline 2007 & 1,52 & 1,56 & 4,32 & 9,80 & 12,66 \\
\hline 2008 & 1,93 & 2,33 & 4,25 & 10,98 & 13,04 \\
\hline Mean & 0,91 & 1,26 & 3,66 & 9,22 & 11,66 \\
\hline
\end{tabular}

In continuation table 3 presents the results of the t-test for equality of means tested for intangible assets and goodwill.

Table 3.

Results of the t-test for equality of means

\begin{tabular}{|c|c|c|c|c|c|c|}
\hline & Sig. (2-tailed) & Croatia & Slovenia & Czech Renublic & Germanv & America \\
\hline \multirow{5}{*}{2004} & Croatia & $x$ & .555 & .537 & .000 & .000 \\
\hline & Slovenia & 132 & $\mathrm{x}$ & 828 & 000 & 000 \\
\hline & Czech Renublic & 329 & 543 & $\mathrm{x}$ & .001 & .000 \\
\hline & Germanv & .000 & .000 & .001 & $x$ & .352 \\
\hline & America & 000 & 000 & 000 & 479 & $\mathrm{x}$ \\
\hline \multirow{5}{*}{2005} & Croatia & $x$ & .194 & .164 & .000 & .000 \\
\hline & Slovenia & 275 & $\mathrm{x}$ & .447 & .001 & .000 \\
\hline & Czech Renublic & 127 & .180 & $\mathrm{x}$ & 147 & .036 \\
\hline & Germanv & .000 & .000 & .231 & $x$ & 332 \\
\hline & America & 000 & 000 & 067 & 360 & $\mathrm{x}$ \\
\hline \multirow{5}{*}{2006} & Croatia & $\mathrm{x}$ & .077 & .117 & .000 & .000 \\
\hline & Slovenia & .755 & $x$ & .607 & .002 & .000 \\
\hline & Czech Renublic & .358 & .220 & $\mathrm{x}$ & .036 & .005 \\
\hline & Germanv & .000 & .000 & .091 & $\mathrm{x}$ & 344 \\
\hline & America & 000 & 000 & 016 & 324 & . \\
\hline \multirow{5}{*}{2007} & Croatia & $\mathrm{x}$ & .066 & .179 & .000 & 000 \\
\hline & Slovenia & 961 & $\mathrm{x}$ & .872 & .003 & .001 \\
\hline & Czech Republic & .379 & .368 & $\mathrm{x}$ & .017 & .005 \\
\hline & Germanv & .000 & .000 & .082 & $\mathrm{x}$ & .619 \\
\hline & America & 000 & .000 & 014 & 349 & $\mathrm{x}$ \\
\hline \multirow{5}{*}{2008} & Croatia & $x$ & .082 & 252 & .000 & 000 \\
\hline & Slovenia & .726 & $\mathrm{x}$ & .981 & .005 & .001 \\
\hline & Czech Renublic & .502 & 531 & $\mathrm{x}$ & .014 & .005 \\
\hline & Germanv & .001 & .002 & .051 & $x$ & .725 \\
\hline & America & 000 & .000 & .009 & .536 & $\mathrm{x}$ \\
\hline & \multicolumn{6}{|c|}{ Sig (2-tailed) - intangible assets } \\
\hline
\end{tabular}

Despite the fact that selected companies are all large companies and their annual reports are prepared according to IFRS (except Slovenian banks, included in the sample that introduced the use of IFRS in 2006 and insurance companies that reported according to IFRS only in 2007; the sample included 1 bank and 2 insurance companies), the structure of 
intangible assets for Slovenian and Croatian selected companies was not always disclosed. The reasons are undoubtedly linked with the insignificance of recognized intangible assets and goodwill, which was confirmed also by the qualitative research. The disclosures of Czech, German and American companies are of a greater extent and provide more detailed information.

In conformity with the results, the research additionally investigates the importance of goodwill as an intangible asset. The results prove that goodwill represents the most important intangible assets for German and American selected companies (figure 3). Their share of goodwill is considerably higher than $50 \%$.

\section{Figure 3.}

The share of goodwill in the structure of intangible assets for the period 2004-2008

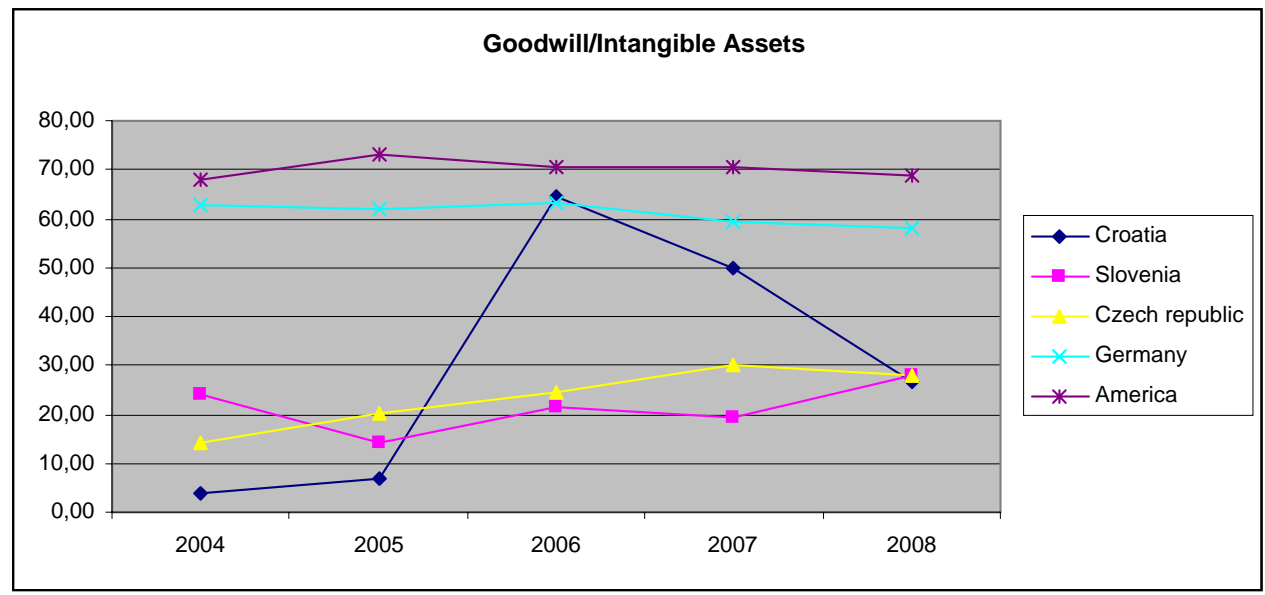

On the other hand an important growth was present in Croatian companies in the year 2006, when goodwill increased to 64, 36 \% (table 4). Despite the growth of goodwill in 2006, the share instantly decreased in 2007 and 2008.

Slovenian and Czech companies did not evident any greater growth nor decrease in the analyzed period. The significance of goodwill in the structure of intangibles was not denoted. The smallest share of goodwill in the analyzed period was present in Slovenian companies. Croatian companies evidenced a greater portion of goodwill in comparison with Slovenian and Czech companies, but goodwill still did not represent the most important intangible asset as it was ascertained for German and American companies.

Table 4.

The proportion of goodwill in the structure of intangible assets in the period 2004-2008

\begin{tabular}{|l|l|l|l|l|l|}
\hline Year & Croatia & Slovenia & Czech Republic & Germany & America \\
\hline 2004 & 3,96 & 24,20 & 14,24 & 62,78 & 67,78 \\
\hline 2005 & 6,78 & 14,07 & 20,34 & 62,07 & 73,07 \\
\hline 2006 & 64,36 & 21,34 & 24,65 & 63,18 & 70,54 \\
\hline 2007 & 49,74 & 19,39 & 30,03 & 59,42 & 70,65 \\
\hline 2008 & 26,60 & 27,86 & 27,81 & 58,04 & 68,98 \\
\hline Mean & 30,29 & 21,37 & 23,41 & 61,10 & 70,21 \\
\hline
\end{tabular}


According to the results of the analysis we can confirm the first hypothesis which stated that the significance of intangibles is less important for post-transition and transition economies in comparison with traditional market economies.

The second hypothesis can be confirmed only partially. There is a significant difference between Slovenia and Croatia in comparison with Germany and America, while Czech companies unexpectedly did not demonstrate the expected difference.

The reasons that lead to these results might be a consequence of the current accounting approach in use. As stated by Powell (2003, 805-806) a significant proportion of internally developed intangibles is not recognized in the financial statement of an entity. The failure to recognize these assets means that investors are not receiving relevant information about the entity. That is why future research approach should analyze the proportion of intangibles that do not meet the criteria for the recognition and to find whether if we take into account both; i.e. recognized and non-recognized intangibles, if the difference between different economies still exists.

According to the results of our analysis, emerging economies will have to dedicate more attention to disclosure items. Just by disclosing more information about non-recognized intangibles, the information asymmetry between recognized and non-recognized intangibles will be eliminated. Recent researches suggest that the lack of information provided by preparers of financial accounts shell be improved (Sevin, Schroeder and Bhamornsiri, 2007, Gerpott et al., 2008). Kristensen and Westlund (2003) believe that it is crucial to understand the gap between market and book value, which is linked with incomplete information about intangibles. Models that could be used to report about financial and non-financial assets are presented by Fincham and Roslender (2003). Research of capital market impacts, of disclosure of enhanced business reporting information, found that disclosures can reduce information asymmetry and improve company valuation (Boedker, Mouritsen and Guthrie, 2008).

Standard preparers, academics, users of financial accounts and financial experts should engage all the necessary efforts to assure an indispensable reporting model which will provide useful, timely, quality and reliable information needed. This is undoubtedly the challenge of the future accounting system.

\section{CONCLUSION}

The results of the analysis prove that there is a significant difference in the share of intangibles (recognized in financial accounts) between market economies and post-transition and transition one. A different picture resulted for the case of goodwill. Despite the fact that differences between Croatia and Slovenia in comparison with Germany and America can be identified, Czech companies do not demonstrate a statistical difference in comparison with market economies. Notwithstanding the fact that recent analysis dealt with the growing importance of intangibles the analysis proves that in the case of Croatia, Slovenia and Czech Republic they do no represent an important asset that is recognized in financial accounts. The increasing trend demonstrates that in the near future also these companies will face a grater changes in the structure of their financial accounts. To that end a major attention to their disclosures shall be provided.

This study is limited to selected companies that are part of the national stock exchange indexes. It could be part of future research to asses these differences also for other economies and different sizes of companies. 


\section{REFERENCES}

Boedker, C., Mouritsen, J., Guthrie, J., (2008), "Enhanced business reporting: international trends and possible policy directions", Journal of human resource costing \& accounting, 12 (1): 14-25.

Boekenstein, B., (2009), "Acquisitions reveal the hidden intellectual capital of pharmaceutical companies", Journal of intellectual capital, 10 (3): 389-400.

Brännström, D., Giuliani, M., (2009), "Accounting for intellectual capital: a comparative analysis", The journal of information and knowledge management systems, 39 (1): 68-79.

Busacca, G. A., Maccarone, P., (2007), "IFRSs and accounting for intangible assets: the Telecom Italia case", Journal of intellectual capital, 8 (2): 306-328.

Dolenc, P., (2009), "Trend brakes in the public debt management in Slovenia", Ekonomický časopis, 57 (1): 95-103.

Dunse, N. A., Hutchinson, N. E., Goodacre, A., (2004), "Trade related valuations and the treatment of goodwill", Journal of property investment \& finance, 22 (3): 236-258.

Edvinsson, L., (2000), "Some perspectives on intangibles and intellectual capital 2000", Journal of intellectual capital, 1 (1): 12-16.

Fincham, R., Roslender, R., (2003), "Intellectual capital accounting as management fashion: a review and critique", European accounting review, 12 (4): 781-795.

García-Ayuso, M., (2003), "Intangibles: Lessons from the past and look into the future". Journal of intellectual capital, 4 (4): 597-604.

Gerpott, T. J., Thomas, S.E., Hoffmann A. P., (2008), "Intangible asset disclosures in the telecommunications industry", Journal of intellectual capital, 9 (1): 37-61.

Hussi, T., Ahonen, G., (2002), "Managing intangible assets - a question of integration and delicate balance", Journal of intellectual capital, 3 (3): 277-286.

International financial reporting standards. Available at:

http://ec.europa.eu/internal_market/accounting/ias/index_en.htm (accessed 15 August 2009).

Kristandl, G., Bontis, N., (2007), "Constructing a definition for intangibles using the resource based view of the firm", Managerial decision, 45 (9): 1510-1524.

Kristensen, K., Westlund, A. H., (2003), „Valid and reliable measurements for sustainable non-financial reporting", Total quality management, 14 (2): 161-170.

Lahovnik, M., (2000), "Uspešnost prevzemov podjetij v Sloveniji v devetdesetih letih", Economic and business review, 2 (February 2000): 131-143.

Lev, B., Daum, J. H., (2004), "The dominance of intangible assets: consequences for enterprise management and corporate reporting", Measuring business excellence, 8 (1): 6-17.

Mergerstat. Available at: https://www.mergerstat.com/newsite/ (accessed 20 July 2009).

Powell, S., (2003), "Accounting for intangible assets: current requirements, key players and future directions", European accounting review, 12 (4): 797-811.

Schroeder, M., (2007), "Goodwill on consolidation as an indicator of progress in transition economies: evidence form Polish listed group financial statements", Research in accounting, banking and corporate financial management in emerging economies, Vol. 7: 1127.

Seetharaman, A., Balachandran, M., Saravanan, A. S., (2004), "Accounting treatment of goodwill: yesterday, today and tomorrow: Problems and prospects in the international perspective", Journal of intellectual capital, 5 (1): 131-152.

Sevin, S., Schroeder, R., Bhamornsiri, S., (2007), "Transparent financial disclosure and SFAS No. 142", Managerial auditing journal, 22 (7): 674-687.

Stubelj, I., (2009), "The cost of equity capital: the case of selected Slovene publicly traded companies", Management, 4 (1), 21-38. 


\section{ZNAČAJ NEMATERIJALNE IMOVINE: KOMPARATIVNA ANALIZA HRVATSKE, SLOVENIJE, ČEŠKE, NJEMAČKE I SAD}

\section{SAŽETAK}

S obzirom na rastuću važnost nematerijalne imovine, cilj istraživanja je utvrđivanje značaja nematerijalne imovine za hrvatska, slovenska, češka, njemačka i američka javna poduzeća. Analiza je usredotočena na nematerijalnu imovinu koja ispunjava uvjete za ulazak u financijska izvješća. Rezultati analize dokazuju da u periodu 2004.-2008. nematerijalna imovina predstavlja bitan dio imovine za gospodarstva s tradicionalnim tržištima, što nije slučaj u post-tranzicijskim i tranzicijskim gospodarstvima, usprkos činjenici da mnoge analize naglašavaju njenu rastuću važnost u današnjem poslovnom okruženju. Buduća bi istraživanja trebala analizirati udio nematerijalne imovine koja ne ispunjava uvjete za prepoznavanje i provjeriti posjeduju li zaista tranzicijska gospodarstva znatno manji udio nematerijalne imovine.

Ključne riječi: nematerijalna imovina, goodwill, komparativna analiza, financijska izvješća 